\title{
Black Disaffection from the Republican Party During the Presidency of Herbert Hoover, 1928-1932
}

\author{
George F. Garcla
}

\begin{abstract}
0
NE MAJOR CHANGE in twentieth-century American voting patterns has been the shift of black Americans from the party of Lincoln to that of Franklin D. Roosevelt. For some historians the real beginning of this shift dates not to 1933 but to 1928 . $^{1}$ In that election year, Herbert Hoover became the first Republican president since Reconstruction to break the Solid South. Buoyed by his unprecedented victory, Republican leaders revived the old lily-white southern strategy in an attempt to permanently capture the South for the G.O.P. ${ }^{2}$ Basically, this policy required purging black Republicans from leadership positions in the southern wing of the G.O.P. and replacing them with respectable, business-oriented southern whites. In theory,
\end{abstract}

'John Hope Franklin, From Slavery to Freedom (New York: Vintage Books, 1969), p. 524. Franklin, the dean of black historians, writes that "the real disaffection of Negroes in the Party of Lincoln began in 1928 when Republicans attempted to resurrect a strong party in the South under white leadership."

2For a history of this lily-white strategy, see Vincent DeSantis, Republicans Face the Southern Question: The New Departure Years, 1877-1897 (Baltimore: Johns Hopkins Press, 1959), pp. 66-103; Vincent DeSantis, "Republican Efforts to 'Crack the Democratic South,' " Review of Politics 14 (April 1952): 247-252; Stanley P. Hirshson, Farewell to the Bloody Shirt (Bloomington: 


\section{Black Disaffection}

adoption of a lily-white stance by the national party leadership would symbolically cut off the party's abolitionist legacy and thus attract southern whites into its ranks. Moreover, respectable white Republican leadership in the South, the Hoover strategists argued, would draw that region into the mainstream of national progress, and a strong two-party system would develop. Gradually, as education, economic development, and the spread of a cooperative spirit changed attitudes and local customs, southern blacks would also be granted the benefits of the American system. ${ }^{3}$ In launching the southern strategy, the Hoover team had expected only a relatively minor response among northern blacks, but this was not what they provoked. Inadvertently, they provided an issue around which the more militant black leaders, the men who had already become thoroughly disenchanted with the "clutches of Republican treachery," " could rally. Quickly denouncing Hoover's call for a "lilywhite party" as a betrayal of American ideals, they mounted an educational and political campaign that had a significant impact on blacks' party loyalties.

The first wave of black protest was touched off by Hoover's official announcement of his administration's plans for the South. To most black editors and journalists, the president's talk of cleaning up corruption, putting the southern G.O.P. in the hands of enlightened public servants, and paving the way for a two-party system in which blacks could eventually participate, was evidence either of sheer hypocrisy or of political ineptitude. To W. E. B. DuBois, for example, the "Great Humanitarian" was either a white supremacist trying to mask a basically racist appeal to the white South, or he was "extremely naive" in his faith that "the political owners of the Solid South"

Indiana University Press, 1962), pp. 21-44; Richard Sherman, The Republican Party and Black America: From McKinley to Hoover, 1898-1933 (Charlottesville, Va.: University Press, 1973).

${ }^{3}$ For an account of Hoover's southern strategy, see George F. Garcia, "Herbert Hoover's Southern Strategy and the Black Reaction" (M.A. thesis, University of Iowa, 1972).

4The phrase is from the Chicago Defender, 4 June 1930, p. 2. 


\section{The Annals of Iowa}

were going to give up the "tremendous power and wealth" that their "political usurpation" had put in their grasp. ${ }^{5}$ Other critics saw much hypocrisy, both in expecting northern blacks to sanction overt discrimination in the South and in Hoover's tendency to see corruption only in the black-dominated Republican organizations, not in such equally corrupt lily-white machines as the one in Texas. In addition to such criticism in the black press, Hoover's announcement also brought hundreds of protesting letters and telegrams from black business leaders, fraternities, churches, and educational institutions, all expressing resentment over his betrayal of traditional Republican ideals. Typical of many of these was a letter from Harry Pace, president of the National Negro Insurance Association, arguing that the movement toward lily-whiteism was not only "unjustifiable" but "un-American and contrary to the fundamental principles of our government." It had, so Pace claimed, "pained the hearts of practically every Negro in America."' Significantly, some black leaders who had backed Hoover in 1928 and early 1929 now became much more critical. One notable example was Robert $R$. Church, the leader of the black political machine in Memphis, who, prior to the president's announcement, had been strongly discounting rumors that the administration would actively push a policy of lily-whiteism. ${ }^{7}$ After the announcement, he began emphasizing the "disappointment of colored people" with the Republican "conspiracy" against them and warning Hoover that the southern strategy adopted by his administration would "leave the Republican party a wreck upon the shores of the political ocean." ${ }^{\prime \prime}$

${ }^{5}$ Crisis 36 (April 1929): 131.

- Pace to Hoover, 27 April 1929, Colored Question file, Presidential Papers, Herbert Hoover Papers, Herbert Hoover Presidential Library, West Branch, Iowa (hereafter cited as HHP).

'Chicago Defender, 8 March 1929, p. 1. Church was quoted as saying: "In my opinion Mr. Hoover will prove a shocking disappointment to both the small but important element of Colored Republicans, who fear that his silence gives consent to their prosecutors, and the close-knit band of famished lilies and suitcase Democrats who expect him to put Colored people back into slavery."

${ }^{8}$ Church to Hoover, 6 November 1929, Colored Question file, HHP. 
This is not to say, of course, that black opinion was unanimous in 1929. Nor was it so strongly anti-Hoover as it would later become. Men likẻ Robert R. Moton still seemed convinced that the president was a genuine friend of the black race, and that once the corrupt black-and-tan leadership was purged from the southern G.O.P., a respectable racially integrated Republican party would emerge as a viable political force in the South. ${ }^{9}$ From Arthur W. Mitchell, who, with the advent of the New Deal, was to switch parties and become the first black Democrat ever elected to Congress, came a similar though less favorable opinion. As he saw it, he told Hoover, those blacks who were aware of the "deplorable conditions in the South" should support efforts to establish a "two-party government," particularly since nothing had "done more to retard the progress of the Negro" than the "incompetent and fraudulent leadership" characteristic of southern Republicanism. Yet extreme lily-whiteism, Mitchell continued, was both unnecessary and undesirable, even as a temporary stage. The goal could be achieved by giving "substantial colored men and women" a share of the responsibility for reform. ${ }^{10}$

Even such friends of the administration, however, found it difficult to maintain their position when the second wave of black protest began taking shape in the spring of 1930 , touched off by Hoover's appointment of Judge John J. Parker of North Carolina to the Supreme Court. Parker's appointment was part of Hoover's overall plan to repay key southern "Hoovercrats" who had given him support by bolting the Democratic party in the election of 1928. To the president this appointment seemed safe enough, particularly since Parker had a distinguished career behind him: first as a relatively popular though unsuccessful Republican candidate for various state offices, then as a

${ }^{9}$ Moton to Walter H. Newton, 22 February 1930, Colored Question file, HHP; Albon Holsey to Francis E. Rivers, 12 October 1932, Colored Question file, HHP; Claude Barnett to George Akerson, 19 November 1930, Colored Question file, HHP. All of these men while supporting Hoover's reform program, did urge the president to appoint able blacks to the revamped G.O.P. organizations in the South.

${ }^{10}$ Mitchell to Hoover, 30 March 1929, Colored Question file, HHP. 


\section{The Annals of Iowa}

highly successful lawyer and special assistant during the investigations into alleged war frauds, and finally in the circuit judgeship to which Coolidge had appointed him in 1925. ${ }^{11}$ Yet once the appointment had been made, opposition from northern critics quickly took shape. Organized labor and its liberal supporters remembered Parker as the judge who had handed down the Red Jacket decision upholding "yellow dogs" contracts, and the NAACP remembered that during his 1920 gubernatorial campaign he had declared "the participation of the Negro in politics" to be "a source of evil and danger to both races." 12

After asking the appointee whether he still held the same views as in 1920 and receiving no reply, the NAACP launched a vigorous campaign against Parker's confirmation. A campaign, so Walter White thought, that eventually developed into "the greatest political demonstration by the Negro since the Civil War." Political pressure was applied through the black press; through letters, telegrams, and phone calls; through petitions and visitations to Congress; and through mass meetings staged in black communities throughout the nation. Never, declared the Chicago Defender, had blacks been so solidly united behind any single political issue. Even Robert R. Moton, Hoover's accommodationist advisor from Tuskegee, was demanding that the administration either withdraw the nomination or "inducé Judge Parker himself to withdraw." Blacks, he told Hoover, could stand much from their "friends," but their "self-respect" would not allow them to "swallow" the deliberate elevation to the Supreme Court of a "man who has openly declared his contempt for them."13

In response to the campaign mounted by the NAACP, the administration induced Parker to issue a statement assuring the "colored people" that he harbored no prejudice against them,

\footnotetext{
${ }^{11}$ Most observers agreed with the Chicago Tribune that the "Judiciary Committee will take favorable action and . . . the Senate will confirm the appointment with little if any opposition." See Chicago Tribune, 22 March 1930, p. 1.

${ }_{12}$ Walter White, "The Negro and the Supreme Court," Harper's 122 (January 1931): 161.

${ }^{13}$ Ibid., p. 162; Chicago Defender, 26 April 1930, p. 1; Moton to Newton (Hoover's secretary), 18 April 1930, Parker file, HHP.
} 
promising that he would not deny them their rights under the Constitution and the law, and declaring that his statement of 1920 had been intended only to keep the race issue out of the campaign and clarify his party's abhorrence of what had happened during the Reconstruction era. As further evidence of his fair-mindedness, publicity was also given to a court decision in which he had held a segregation ordinance to be unconstitutional and to statements from the few blacks who could be persuaded to endorse him, the most notable being James E. Shepard, president of North Carolina's college for blacks. ${ }^{14}$ Such arguments, however, failed to check the mounting protest, which by now was having a noticeable effect upon northern senators with large black constituencies. Sentiment against Parker was so pronounced that some administration leaders could not believe that the blacks alone were responsible. Behind them, they suspected, was a "conspiracy" of southern Democrats. Yet when the FBI was ordered to investigate this possibility, it could find no supporting evidence. ${ }^{15}$

In the end, by a close vote of forty-one to thirty-nine, the forty-one including nine Republicans who had ordinarily supported the administration, Hoover's appointee was rejected. ${ }^{10}$ When confronted with threats from labor and from "a black association" who had opposed the judge on the "wholly fictitious" grounds that he had made "some remark bearing on white supremacy," the president later recalled, the Republican senators had run "like white mice." ${ }^{17}$

${ }^{14}$ Dictation by telephone, Parker to Miss McGraw, 24 April 1930, Parker file, HHP; Parker to Congressman David H. Blair, 9 April 1930, Parker file, HHP; "Answer to Charge that Judge Parker Advocated Denial of Rights to Colored People," memorandum, undated, Parker file, HHP.

${ }^{15}$ Memorandum, 25 April 1930, Parker file, HHP. According to this memorandum Mabel Willebrandt suggested the investigation.

${ }^{16}$ Chicago Tribune, 8 May 1929, p. 1 . Fourteen southern senators voted against the appointment, eleven for confirmation. Of the thirty-nine who voted for Judge Parker's confirmation, twenty-nine were Republicans; ten were Democrats. The forty-one against included seventeen Republicans, twenty-three Democrats, and one Farmer-Laborite.

${ }^{17}$ Herbert Hoover, Memoirs, vol. II, The Cabinet and the Presidency, 19201933 (New York: MacMillan Co., 1952), p. 269. 


\section{The Annals of Iowa}

As noted previously, the NAACP's unprecedented campaign against Parker's confirmation enjoyed the support of almost all ' black leaders, militants and accommodationists. The fact that Parker was not confirmed served to encourage and strengthen those who had long advocated the adoption of a pressure-group approach. With this plan, a united black community, acting through appropriate political organizations, would reward its friends and punish its enemies regardless of their party affiliations. After the Parker incident, wrote Heywood Broun in November 1930, Republican politicians could no longer say with assurance that every black citizen who went to the polls could be counted as another Republican vote. The old ties had been loosened, and there was a growing chance that they might slip away entirely. ${ }^{18}$

One indication of the extent to which these successive waves of black protest had altered party loyalties came in the mid-term elections of 1930, especially in states where the NAACP had set out to defeat Republican senators who had voted for Parker's confirmation. In Kansas, in particular, a strong campaign was mounted against Senator Henry J. Allen, the man who had directed the pro-Parker forces in the state. Eventually, even though Allen did his best to counter the NAACP's effort and the administration sent in a black assistant attorney general to speak in his behalf, the campaign was successful. Traditionally, Republican senatorial candidates in Kansas had been able to count on at least seventy-five percent of the black vote. But in 1930, thanks to the NAACP's efforts, Allen received less than twenty-five percent, a defection large enough to give his Democratic opponent a narrow victory. ${ }^{19}$ In Ohio, the NAACP scored a similar victory. There blacks organized against Senator Roscoe C. McCullough, another supporter of Parker's confirmation. Since depression conditions and the

\footnotetext{
${ }^{18}$ Heywood Broun, "The Black Voter," Crisis 37 (November 1930): 369.

${ }^{19}$ Memorandum, Walter White to Mr. Bagnall, Mr. Pickens, and Dr. Dubois, undated, Records of the NAACP, Manuscript Division, Library of Congress; Telegram, White to Sumer A. Purniss and W. C. Houston, 23 April 1930, Records of the NAACP; William Pickens, "The Negro Voter and Allen," Crisis 37 (October 1930): 338.
} 


\section{Black Disaffection}

attractive personality of the Democratic candidate, Robert J. Bulkley, had combined to make the senatorial contest an unusually close one, the black organizations found themselves holding the balance of power. In Toledo, Columbus, Akron, and Canton, black voters supported Bulkley by a margin of three to one, thus helping insure McCullough's defeat. ${ }^{20}$

Elsewhere, the NAACP was less successful. In Rhode Island, for example, it had marked Senator Jesse $H$. Metcalf for defeat, and in Delaware, it campaigned against Senator Daniel H. Hastings. But in both states, even though large numbers of black voters did desert the Republican party, the senators managed to squeak through to narrow victories. The successes that were scored, however, demonstrated clearly that Republican politicians could no longer take the black vote for granted. Given the new sense of militancy and alienation, the new confidence in pressure-group politics, and the heightened race consciousness stimulated by protests against Hoover's program for the South, those who supported the outlook exemplified in Parker's appointment could find the political costs to be high. ${ }^{21}$

$W_{\text {hile demonstrating a political punch in } 1930 \text {, black critics }}$ continued to expose instances of Hoover's "racism," instances that in many cases were merely political blunders rather than parts of the calculated conspiracy that was usually assumed in the black press. One celebrated incident occurred in July 1930 when the War Department, after inviting the Gold Star Mothers to visit the graves of their sons in France, proceeded under orders from Secretary of War Hurley to organize segregated transportation separating the white mothers from the black. Exposed in the press, the incident created an immediate furor, drawing sharp comments from both black leaders and white

${ }^{20}$ White, "The Negro and the Supreme Court," pp. 224, 225.

${ }^{21}$ Franklin, From Slavery, p. 526. The NAACP's campaign against the proParker Republican senators did not end in 1930. In 1932 it urged the defeat of Senators Samuel Shortridge of California, Hiram Bingham of Connecticut, and James E. Watson of Indiana. In 1934 it made similar efforts to unseat Simeon Fess of Ohio and Felix Hebert of Rhode Island. 
liberals and generating political repercussions still felt two years later. To black critics, it seemed that a federal discrimination which had long been "fostered, cherished, condoned, and practiced," and which had become "glaringly flagrant, intensified, and widened" since 1929, had now "reached the point of cruel humiliation." 22 To liberal journals like The Nation, it was an "incredibly stupid and ungracious gesture," demonstrating the administration's inability to see blacks as "American citizens" rather than "property to be shoved around back alleys and smuggled in at side doors." ${ }^{23}$ And to black voters it was a grievance to be remembered. Writing from California in 1932, Mark Requa would note the tremendous "bitterness and resentment" felt by the state's blacks, largely, he thought, because they remembered "the Gold Star Mothers being sent in a 'cattle ship;" and because of the president's silence and apparent approval of the action. ${ }^{24}$

A second incident, also used as proof of Hoover's "racism" and again stemming from orders issued by the War Department, involved alleged discrimination against the Tenth Cavalry, a black army unit. As an economy move in 1931, the size of the army was being cut. But as Robert Moton and other black leaders pointed out, the scheduled reduction of the Tenth Cavalry was far greater than that projected for white units. The aim, they thought, was to turn the organization into a service regiment, a change that would seriously damage the morale of black troops. To make the discrimination all the more obvious, the pertinent orders had cancelled promotions in the unit and placed a ceiling on the number of black officers that it might have. ${ }^{25}$

Confronted with the protest from Moton, who, after all, was an administration supporter, Hoover did order an investigation. But having been assured by acting Secretary of War F. J. Payne

\footnotetext{
${ }^{22}$ Newspaper clipping, Philadelphia Tribune, 17 July 1930, Colored Question file, HHP.

${ }^{23}$ Nation 131 (23 July 1930): 85-86.

${ }^{24}$ Telegram, Mark Requa to Newton, 23 April 1932, Colored Question file, HHP.

${ }^{25}$ Moton to Hoover, 18 September 1931, War Department file, HHP.
} 


\section{Black Disaffection}

that efficiency, not discrimination, was the goal, and that the black troops involved were satisfied with "the conditions of their service," he took no corrective measures. "After further review of the subject," he told Moton, "I am convinced that the present orders do not discriminate against colored enlisted men and that they are necessary for the best interests of National defense." ${ }^{26}$ Moton, whose interest in the subject stemmed partly from his military background and pride in the record of black military units, still thought otherwise. ${ }^{27}$ Significantly, so did the leaders of the NAACP and eventually, after the matter had been publicized, most of the black community. "Among colored people and in the colored press," wrote Roy Wilkins in late October 1931, the feeling had become general that the War Department and the Hoover administration were proceeding with a program that would "reduce their soldiers to the status of labor battalions." ${ }^{28}$ In the months that followed, as Hoover continued to support the scheduled reduction, the issue remained alive and became one more grievance in the indictment that black critics were drawing up against the president and the Republican party.

As further proof of Hoover's racism, such critics also frequently pointed to four other matters: his policy toward the black nation of Haiti, his alleged discrimination against blacks in making appointments to federal service, his refusal to move beyond ritualistic studies in tackling the social problems of the black minority, and his seeming willingness to tolerate lynching and violence in the South. In all of these matters, so the charge ran, the president was acting like a white supremacist and dedicated enemy of the black race, either because he in fact was one or because he hoped that his stance would pay political dividends in the South.

${ }^{26}$ Memorandum, Payne to Hoover, 6 October 1931, War Department file, HHP; Hoover to Moton, undated, War Department file, HHP.

${ }^{27}$ William Hardin Hughes and Frederick D. Patterson, Robert Russa Moton of Hampton and Tuskegee (Chapel Hill: University of North Carolina Press, 1956), p. 68.

${ }^{28}$ Memorandum, Roy Wilkins to Walter White, 20 October 1931, War Department file, HHP. 
In regard to Haiti, a nation that had been under the control of the United States since the Wilson administration, three charges were frequently made. One accused Hoover of perpetuating a racist-oriented imperialism by refusing to give Haitians their complete independence. The second saw definite proof of racism in his failure to appoint a single black to the special commission that was set up to consider the possibilities of home rule. And the third, added toward the end of his administration, charged him with sabotaging the work of the commission and refusing to adopt the timetable for withdrawal that it had recommended. His critics, moreover, were not appeased when he did appoint a black commission, headed by Robert Moton, to study and make recommendations for the improvement of the Haitian educational system. This was too little and too late, and, as Moton himself conceded, was largely "overshadowed in the popular mind by the fact that no Negro was on the Haitian Commission as such." 29

The second item charging Hoover with making "fewer firstclass appointments of Negroes to office than any President since Andrew Johnson" was widely accepted in the black community, but could also be legitimately debated. ${ }^{30}$ The emphasis in making the charge was usually upon the Haitian Commission, the replacement of black-and-tans (southern black factions of the G.O.P.) with lily-whites, and the continuation of inherited policies of employment discrimination, both in the number of blacks appointed and in the assignment of most of them to menial tasks. Only rarely did Hoover receive credit for making the traditional black appointments, those, for example, to the office of Recorder of Deeds; the Ministry of Liberia; the municipal judgeship in Washington, D.C.; and the collectorship of internal revenue in New York City. Still more rarely was it noted that working in cooperation with Robert Moton he had raised the total number of black employees in the federal service to a figure of 54,684 and had considerably increased the number of black appointments to such posts as business specialist,

${ }^{29}$ Crisis 39 (November 1932): 362; Moton to Newton, 22 February 1930, Colored Question file, HHP.

${ }^{30}$ Crisis 39 (November 1932): 362. 


\section{Black Disaffection}

education advisor, assistant solicitor, and assistant district attorney. A later black publication would concede that Hoover did make as many "first-class" black appointments as Harding and Coolidge combined, but during his presidency blacks found this exeedingly difficult to believe. ${ }^{31}$

The third matter, Hoover's alleged use of ritualistic studies, conferences, and public relations committees as substitutes for real action, was a part of the general charge of "do-nothingism" that plagued Hoover's administration as the depression set in. In reality, the president did order or sponsor several worthwhile studies into the problems of black housing, education, child care, and job opportunities. To conduct these, he appointed a number of black study or advisory committees. Through special divisions of the Committee on Recent Social Trends, the White House Conference on Housing, the National Advisory Committee on Education, for example, he subjected various aspects of the "Negro Problem" to scientific inquiry. Through his long-time connections with the Julius Rosenwald Fund, he arranged for the funding of and participated in the planning that led up to a Conference on the Economic Status of the Negro. ${ }^{32}$ Yet to his critics, the studies themselves were merely ways of postponing needed reforms and masking inaction, while the black committees involved were nothing more than

${ }^{31}$ Newspaper clipping, Washington Times, 14 November 1930, Colored Question file, HHP; Moton to Hoover, 15 January 1930, Colored Question file, HHP; Moton to Hoover, 5 February 1930, Colored Question file, HHP; Moton to Newton, 22 February 1930, Colored Question file, HHP; Newton to James J. Davis, 25 March 1930, Colored Question file, HHP; "Federal Government," memorandum, undated, Colored Question file, HHP; Monroe Work, ed., Negro Year Book, 1937-1938 (Tuskegee Institute: Negro Year Book Publishing Co., 1937), p. 112.

32 "Report of the President's Research Committee on Recent Social Trends," Recent Social Trends in the United States (New York: McGraw-Hill Book Company, Inc., 1933), pp. 553-601; John Gries and James Ford, eds., Report of the Committee on Negro Housing (Washington, D.C.: National Capital Press, Inc., 1932); Ray Lyman Wilbur and Arthur Mastick Hyde, The Hoover Policies (New York: Charles Scribner's Sons, 1937), pp. 84-86; Crisis 39 (January 1932): 468; "Report on the Conference on the Economic Status of the Negro," 29 October 1930, Colored Question file, HHP. Interestingly, all of these studies recommended more federal intervention to aid blacks. 
the worst sort of tokenism. "Only the silliest Negro," declared the Chicago Defender, could believe that membership on a "Negro committee here" and a "Negro committee there" was any real substitute for an equitable appointment policy. And unless Hoover purged himself of this fallacy, the paper threatened, there would be another "Negro committee" giving him a good deal of trouble in 1932..$^{33}$

Hoover's alleged toleration of lynching and violence in the South, was used to complete the image of a racist, do-nothing, politically motivated president. There had been thirteen more lynchings in 1930 than in 1929, but Hoover's response that this was "undermining of the very essence of both justice and democracy" did not satisfy his black critics, who wanted more than verbal condemnation. ${ }^{34}$ He made no move to sponsor a federal anti-lynching law. In one incident, his southern strategy could be held responsible for murder of a black man by a white mob. On July 29, 1930, S. S. Mincey, a black-and-tan leader in Montgomery County, Georgia, had refused to cooperate with an adminstration-backed lily-white group, had been threatened with violence for his failure to do so, and later that evening had been taken from his home and flogged to death. The administration's chief reaction was to regard the incident as "unfortunate." ${ }^{35}$

A s Hoover's term wore on, and new evidence of his alleged
racism kept coming to light, the initial sense of grievance among
blacks, caused by the launching of his southern strategy, tended
to grow. Because of Hoover's poor image, many blacks seemed
ready to break their ties with the Republican party, although
this, of course, was not the only motivation. Black Americans,
to an even greater extent than most of their fellow citizens, were

${ }^{33}$ Chicago Defender, 25 April 1931, p. 14.

${ }^{34}$ Hoover to S. H. Reading, 13 August 1930, Colored Question file, HHP.

${ }^{35}$ Arthur F. Raper, The Tragedy of Lynching (Chapel Hill: University of North Carolina Press, 1933), pp. 172-202; Josiah T. Rose to Walter Brown, 30. July 1930, Republican Party in Georgia file, HHP; Ben Davis to Walter Newton, 4 August 1930, Republican Party in Georgia file, HHP; Rose to Newton, 7 August 1930, Republican Party in Georgia file, HHP; Newton to Davis, 13 August 1930, Republican Party in Georgia file, HHP; Rose to New- 


\section{Black Disaffection}

suffering from depression conditions. Already a marginal group employed chiefly in unskilled jobs or domestic service, they now became the first fired and last hired (particularly when whites wanted their jobs). Many slipped toward a submarginal level or a meager existence on relief, and others lost their tenuous hold on middle class status that had been achieved during the 1920s. Consequently, they fully shared the general disillusionment with the Republican economic policies and Hoover's inability or unwillingness to cope with the crisis or even to provide adequate relief. He was, many of them concluded, not only a racist but also an inept and unfeeling president, one from whom the black community could expect neither gratitude, equity, nor wisdom. Probably, even if he had not attempted to woo the white South or become involved in policies that seemed overtly racist, many blacks would still have turned against him and his party for economic reasons.

By early 1932 the two motivations combined to produce a disillusionment among blacks that had become stronger than ever. The southern strategy, the clumsy handling of issues important to the black community, and the lack of success in dealing with the economic crisis were all receiving unprecedented attention in the black press and among black activists. The administration, instead of developing the "understanding of . . . Negro psychology" that Claude Barnett of the Associated Negro Press had found lacking in 1930, seemed bent upon alienating an even larger proportion of a group that had once been solidly Republican. ${ }^{36}$ This group, in spite of its disgust with Hoover and its punishment of pro-Parker Republicans, was still somewhat reluctant to break the emotional attachments of the past, endanger the material benefits provided by some local Republican machines, and join a rival party whose southern wing was

ton, 4 September 1930, Republican Party in Georgia file, HHP. Rose initially blamed an intra-Masonic fight between Mincey and other blacks for Mincey's death, but after an investigation by the Atlanta Interracial Commission had brought out the facts, he was forced to admit that Mincey had died at the hands of the lily-whites.

${ }^{36}$ Claude A. Barnett to George Akerson, 19 November 1930, Colored Question file, HHP. 
openly racist. Straw polls conducted by Opportunity, the Urban League's official publication, showed that a majority of the blacks surveyed in April 1932 now intended to support the Democrats, and that in May this majority had grown larger. However the shift was still not an overwhelming one and was far more pronounced among active blacks in the southern and border states than it was elsewhere. ${ }^{37}$

After the election it became evident that to a considerable extent the traditionally Republican blacks had fulfilled expectations by voting Democratic. In the cities of New York, St. Louis, Philadelphia, Pittsburgh, Indianapolis, Columbus, Toledo, Akron, Boston, Baltimore, and Kansas City, the rate of black defections had been particularly high. Even in Republican Iowa, Democrats had done well in the black precincts of Des Moines and Waterloo. ${ }^{38}$

The change on the part of blacks was, of course, not so great as it would become later. A majority, despite all the furor about Hoover's racism and many economic grievances, continued to vote Republican, either from habit or because Roosevelt and the Democrats seemed unlikely to make them very welcome in the rival party. In cities like Chicago, where the local Republican machine monopolized the distribution of patronage, blacks were naturally reluctant to leave the party of the Great Emancipator. In Chicago, in fact, the percentage of the vote that Hoover received in the black wards actually increased from seventy-five in 1928 to seventy-seven in $1932 .{ }^{39}$ Still, the black

${ }^{37}$ Ira D. Reid, "Opportunity Presidential Candidates Poll," Opportunity 10 (April, May 1932): 115, 141. The April poll gave the Republicans 1,168 votes; the Democrats 1,344; the Socialists 132; and the Communists 32 . The May poll gave the Democrats 2,064 votes; the Republicans 1,655; the Socialists 199; and the Communists 51.

${ }^{38}$ Arthur Krock, "Did the Negro Revolt?" Opportunity 11 (January 1933): 19; Gunnar Myrdal, An American Dilemma (New York: Harper and Brothers, 1944), p. 496; James Braddis Morris, Jr., "Voting Behavior in Four Negro Precincts in Iowa Since 1924" (M.A. thesis, University of Iowa, 1946), p. 28.

${ }^{39}$ Franklin, From Slavery, p. 527; John Schact, "The Shift in the Negro Chicago Vote from the Republican to the Democratic Party, 1928-1939" (M.A. thesis, University of Iowa, 1966), pp. 1-2; Harold F. Gosnell, Negro Politicians (Chicago: University of Chicago Press, 1935), p. 32. 
exodus had been substantial, and political commentators, who in 1928 had been speculating about the future of the Republican party in the South, were now analyzing the future of the blacks in the Republican party. Writing in Opportunity, Arthur Krock of the New York Times joined with various black spokesmen in attributing the black defections to "Hoover's lily-white Southern policy; his nomination of Judge John J. Parker of North Carolina to the Supreme Court; the jim crowing of Negro gold star mothers in France; failure to reward Negroes with patronage; and the distribution of Negro regiments in the regular army. ..." But when it came to assessing the significance of the defections, Krock was inclined to disagree with those who saw them as permanent breaking away by blacks from their "traditional moorings." The issues, he argued, were temporary in nature, and for this reason, the black shift itself was likely to be only temporary. Blacks would "vote Republican again," he concluded, provided the party showed "the least reason to merit it." 40

Hoover's southern strategy failed miserably as conditions in the South were not propitious for Republicanizing the region. The poorly conceived and badly implemented efforts to do so worked in conjunction with the depression, the neglect of urban problems and sensitivities, and Hoover's image as a racist in the black press, to move a large segment of urban blacks to break their traditional political ties, thus setting the stage for the greater transformation associated with the New Deal. 336.

${ }^{40}$ Krock, "Did the Negro Revolt?" p. 19; Opportunity 10 (November 1932): 
Copyright of Annals of Iowa is the property of State of Iowa, by \& through the State Historical Society of Iowa and its content may not be copied or emailed to multiple sites or posted to a listserv without the copyright holder's express written permission. However, users may print, download, or email articles for individual use. 